\title{
Strategic Planning for Xiaomi: Smart Phones, Crisis, Turning Point
}

\author{
Lung-Tan $\mathrm{Lu}^{1}$ \\ ${ }^{1}$ Fo Guang University, Taiwan \\ Correspondence: Lung-Tan Lu, Fo Guang University, Taiwan. \\ Received: October 14, 2016 \\ Accepted: July 6, 2017 Online Published: July 14, 2017 \\ doi:10.5539/ibr.v10n8p149 \\ URL: https://doi.org/10.5539/ibr.v10n8p149
}

\begin{abstract}
The aims of this case study are to design, practice, and evaluate a group of comparative strategies for one of the leading smart phone companies in the world: Xiaomi Inc. to turn a crisis into an expansion opportunity. First, the worldwide market of smart phones is illustrated. Second, we show the highly competition of smart phones in China market. Third, the de velopment of Xiaomi Inc. is overviewed. Finally, we use several strategic matrixes: (1) IFE, (2) EFE, (3) CPM, (4) SWOT, (5) SPACE, (6) BCG, (7) IE, (8) GSM, (9) QSPM to evaluate and develop strategies for Xiaomi so as to change crisis into a turning point.
\end{abstract}

Keywords: smart phone, strategic matrix, strategic planning, Xiaomi

JEL: D7, L1, L6, M0, M1

\section{Global Smart Phones Market}

The sales of smart phones worldwide in 2016 were over 1.5 billion, 5\% growth year on year, in which the expansion power mainly came from emerging markets such as Asia Pacific region, East Europe, Middle East and North Africa. In the end of 2016, all mature markets except Japan saw weak demand but most of the emerging countries saw strong demand in smart phones. Ten vendors form the top 14 were Chinese companies. Due to the slowing demand of smart phones from 2016, most of these companies staring in peripheral technologies such as, wireless charging, augmented and virtual reality, multiple-lens camera solutions, sensors: biometric authentication and technologies, virtual personal assistants, flexible/curved displays, Wi-Fi 802.11 standards, USB Type-C, and embedded SIM and so on (See Table 1).

Table 1. Top 14 Smartphones Companies Worldwide (2014-2016) Unit: millions

\begin{tabular}{lcccccc}
\hline \multicolumn{1}{c}{ Company (Nation) } & $\begin{array}{c}2016 \\
\text { units }\end{array}$ & $\begin{array}{c}\text { Market Share } \\
(\%)\end{array}$ & $\begin{array}{c}2015 \\
\text { units }\end{array}$ & $\begin{array}{c}\text { Market Share } \\
(\%)\end{array}$ & $\begin{array}{c}2014 \\
\text { units }\end{array}$ & $\begin{array}{c}\text { Market Share } \\
(\%)\end{array}$ \\
\hline Samsung (S. Korea) & 308.9 & 20.8 & 322.0 & 22.4 & 314.2 & 24.2 \\
Apple (USA) & 215.4 & 14.5 & 231.4 & 16.1 & 192.7 & 14.8 \\
Huawei (China) & 139.0 & 9.4 & 108.0 & 7.5 & 75.0 & 5.8 \\
Oppo (China) & 91.0 & 6.1 & 50.0 & 3.5 & 29.9 & 2.3 \\
Vivo (China) & 73.0 & 4.9 & 40.5 & 2.8 & 19.5 & 1.5 \\
ZTE (China) & 57.0 & 3.8 & 57.2 & 4.0 & 46.1 & 3.5 \\
LG (S. Korea) & 55.1 & 3.7 & 59.7 & 4.2 & 59.1 & 4.5 \\
Xiaomi (China) & $\mathbf{5 4 . 3}$ & $\mathbf{3 . 7}$ & $\mathbf{7 1 . 0}$ & $\mathbf{4 . 9}$ & $\mathbf{6 1 . 1}$ & $\mathbf{4 . 7}$ \\
Lenovo (China) & 53.1 & 3.6 & 76.3 & 5.3 & 95.2 & 7.3 \\
TCL (China) & 38.0 & 2.6 & 43.5 & 3.2 & 41.4 & 3.2 \\
Gionee (China) & 30.6 & 2.1 & 20.0 & 1.4 & 19.2 & 1.5 \\
Meizu (China) & 22.0 & 1.5 & 20.2 & 1.4 & 4.4 & 0.3 \\
LeEco/Coolpad (China) & 21.5 & 1.5 & 30.5 & 2.1 & 45.2 & 3.5 \\
Asus (Taiwan) & 20.0 & 1.4 & 16.0 & 1.1 & 5.0 & 0.4 \\
Others & 302.0 & 20.4 & 331.5 & 23.1 & 342.0 & 26.3 \\
Total & 1480.9 & 100 & 1437.3 & 100 & 1300.6 & 100 \\
\hline Source: IC Insights
\end{tabular}

Source: IC Insights, Gartner, TomiAhonen Phone Book 2016, company reports

\section{Smart Phones Market in China}

In China's, the world's largest smartphone market, the Top 5 companies have been closely matched competitors for years. It is not necessarily to be very profitable in China market, however, as most of the competitors in the world are willing to enlarge their market shares as main goal. 2015 was a critical year for smart phones companies in China. The first quarter of 2015 was the very first time the sales of smart phones declined. One of 
the major reasons was the Penetration of the smart phones in the main cities were over $95 \%$. In 2011, the sales growth of smart phones in China was 150\%, 120 millions units, but kept declining every year and was only $2 \%$ in 2015, 470 millions units. In 2016, the new types of smart phones in China market only 1376 models, down $29.5 \%$ year on year. Counterpoint Research, a leading IT research company, estimate the smart phones manufacturing companies would down from 300 in 2015 to 150 in near future. On the other hand, the growth rates of average labor costs in China were $9.1 \%$ form 2012 to 2014. The challenge would be higher than even when the demand is declining and cost is increasing sharply.

Table 2. Top 5 Smartphone Companies in China (2014 - 2016) unit: millions

\begin{tabular}{lcccccc}
\hline Company & 2016 & $\begin{array}{c}\text { Market Share } \\
(\%)\end{array}$ & $\begin{array}{c}2015 \\
\text { units }\end{array}$ & $\begin{array}{c}\text { Market Share } \\
(\%)\end{array}$ & $\begin{array}{c}2014 \\
\text { units }\end{array}$ & $\begin{array}{c}\text { Market Share } \\
(\%)\end{array}$ \\
\hline OPPO & 78.4 & 16.8 & 35.3 & 8.2 & 22.3 & 5.3 \\
Huawei & 76.6 & 16.4 & 62.9 & 14.6 & 41.3 & 9.7 \\
Vivo & 69.2 & 14.8 & 35.1 & 8.2 & 24.1 & 5.7 \\
Apple & 44.9 & 9.6 & 58.4 & 13.6 & 31.1 & 7.3 \\
Xiaomi & $\mathbf{4 1 . 5}$ & $\mathbf{8 . 9}$ & $\mathbf{6 4 . 9}$ & $\mathbf{1 5 . 1}$ & $\mathbf{5 7 . 8}$ & $\mathbf{1 3 . 6}$ \\
Others & 156.7 & 33.5 & 173.3 & 40.3 & 247.0 & 58.3 \\
Total & 467.3 & 100 & 429.9 & 100 & 423.6 & 100 \\
\hline Sour & & & & &
\end{tabular}

Source: IDC Qarterly Mobile Phone Tracker

\section{Xiaomi Growing by Leaps and Bounds}

It is believed that high-quality technology doesn't need to pay high price by the founder and CEO of Xiami Inc, Mr. Lei Jun. Since 2010, Mr. Lei with 11 co-founders have been creating remarkable hardwares, softwares, and internet services for their customers, called Mi fans by incorporating their feedback into our products and services. The logo of Xiaomi, MI, symbolize for "Mobile Internet", on the other hand, "MI" also has other meaning, Mission Impossible, since this company challenges something impossible for this industry and rivals. The logo of MI overturned is "WI", which means Mi fans can enjoy Xiaomi's products without trepidation in Chinese.

Xiaomi advertise one of the keys to its success: saving money on commercials in helping keeping the overall price lower. For Apple's iPhone, premium starts at around US\$700 and it's about US\$ 600 for another rivail, Samsung. Howe ver, in 2011, Mi 1 has similar functions as its rivials but only sold in half price: US\$ 325 (RMB 1999). In 27 September 2016, Xiaomi announced Mi5s, which equipped with Snapdragon 821, 3GB RAM / 64GB ROM, 5.15" inch screen with the price same as Mi 1. Xiaomi relied on Mi fans to spread the word in attracting new customers through social media. Xiaomi mainly use Weibo and MiTalk to be its social media to connect with fans and prospective customers in China market. Xiaomi has been pro-active in running its own community forums: MiTalk. This is a social media where the Mi fans meet to discuss devices, share experience and knowledge, and usually hang out. On Weibo and MiTalk, there are numerous posts on a variety of topics such as feedbacks of products, flash sales, and photo form daily life.

The CEO of Xiaomi, Mr Mr. Lei Jun said the triangle of Mi products and services are: hardware, software, internet services. In August 2011, Xiaomi released their first smart phone: Mi 1 and received huge success. The sales of smart phones from 2012 to 2015 were 7.1 millions to 65.6 millions. (See Table 3) The hardware products for Xiaomi presently include the Mi series, Redmi series, Mi TV, and smart home ecosystem. With more than 65 million smart phones sold in 2015 worldwide, and products launched in Asia (Tai wan, Hong Kong, Singapore, Malaysia, Philippines, India, and Indonesia) and Americas (USA and Brazil), Xiaomi is planning to expand its footstep across the world to grow to be a global brand. Creating a first class global company has been a dream for Mr. Lei, the CEO of Xiaomi. Xiaomi's organizational culture is: "Just for fans" and it's company's belief. Our Mi fans lead us on the way to "always believe that something wonderful is about to happen". As a te am to deliver wonderful for fans, we share the same persistent chase of excellence, always refining and improving our products and services to deliver the best user experience for Mi fans. We are also courageous in testing new technologies; realize dreams, commitment in innovation, and pushing industrial boundaries into unique Mi products and services with fully supports from Mi fans.

There are five best products in Xiaomi history. Mi4 - is a huge hit from Mi fans. Even today, it has not lost its significance. This smart phone has a Snapdragon processor 801 with 3 GB RAM, equipped with a 5 "inch display. Smart phone has recently updated to the latest MIUI V8. However, the most up-to-date flagship smart phone is Mi 5s, which equipped with Snapdragon processor 821, 4G RAM, 5.15" inch display, and better than ever camera. Second one would be the earphone, Piston 3 Youth Edition, with excellent sound quality congregation is most likely the best headset from Xiaomi in terms of CP value. The third one is Smart TV Mi TV 
3, was the most feature-rich and hi tech TV. It has an attractive 60 "inch display with $4 \mathrm{~K}$ resolution. However, the newest one is Mi TV 3s, which equipped with 65" inch display of 4K resolution, Surround Theater Sound, 64 bit CPU and massive drama programs. The forth one is Mi Band, which is probably the most popular wearable device in the world. Xiaomi sold 12 million Mi Band in 2015 and 5.8 millions in the first half 2016. Bracelet Mi Band may trace steps, to inform user about incoming notifications on smart phone, as well as to act as an intelligent vibration alarm. The final one is Action Camera Xiaomi Yi Sports, which is a protected sport camera in a case. The Yi camera equipped with 16 mega pixel sensor, F2.8, angle of 155 degrees and resolution of $4608 \times 3456$ pixels. Users can record video in Full HD resolutions. Recently, Xiaomi announced the second generation of Yi sport camera, which provided 4K video recording and 2.19" inch touch screen. In 2016, Xiaomi changed their policy to use three brand representatives, which believed to gain consumers from OPPO and Vivo. Xiaomi announced their Mi 6 flagship smartphone in April, 2017, hopping to regain its hi-end market shares.

MIUI is the operation system (OS) for Mi smart phones and tablet computers, based on the OS of Google Android. Since16 August 2010 MIUI launched the vision 1, it has been more than 200 million handsets installed MIUI ROM and the latest vision is MIUI 8 stated on 22 September 2016. Unlike other smart phone rivals, Xiaomi provides customized MIUI for to be flashed for other brands such as Samsung, HTC, LG, and Nexus: over 340 model handsets are supported.

Although Xiaomi still is one of the most popular smart phones maker, but overall shipment units are shrinking quickly. Rivals, Oppo and Vivo grew at a massive 124\% and 74\% year-on-year, while sales of Xiaomi volumes decreased by nearly $40 \%$. Most of Xiaomi's products are sold on line. Most companies use their homepages as showrooms or online adverts. However, Xiaomi, build its homepage as a purely e-commerce store. Since 2014, Xiaomi's homepage has been the third largest, behind Taobao and JD, business-to-consumer (B2C) e-store in China in terms of sales volume. With the intention of catch up to its tough competitors such as Huawei, Lenovo, Oppo and Vivo, Xiaomi is going to change once it proud with business model: on-line sale only into opening 1,000 stores in near future.

Global smartphone shipments grew 7\% sequentially in Q3 2016. Tarun Pathak, Sr. Analyst at Counterpoint Research stated that performance in the China, India and US smartphone markets is becoming a determining issue in the worldwide growth as these three markets now account for more than half of the total shipments worldwide. Since 2015, Xiaomi is looking to replicate its success in India. Manu Jain, India head of Xiaomi, said that in the third quarter 2015, Xiaomi crossed sales of 1 million units and repeated this feat in the following quarter. Xiaomi launched an India-focused smart phone and not only sell through Flipkart, biggest e-store in India, but also through other channels such as Amazon, Aitel stores. Xiaomi seems to be confident of meeting the 30 per cent local sourcing norm and set up own stores, telecom industry sources said the average value addition in assembling of mobile handsets in India by foreign players is less than 10 per cent. Indian government is trying to raise value-addition by foreign smart phone makers in India from less 10 per cent to 30 per cent. By keeping 1 per cent excise duty on domestic assembling factories and 10 per cent customs duty, many foreign smart phone makers such Foxconn, Asus, Acer, Inventec, Lenovo, and Huawei are building their own Indian factories to reduce costs. Indian smartphone market has overcame by the top four Chinese rivals: Xiaomi, Lenovo, Oppo and Vivo, pushing out the Indian players from the list of top 5 in 2016. Chinese players keep strengthening their seize in Indian smartphone market. In the first quarter of 2017, these Chinese players gained 51.4\% of the market in India with $142.6 \%$ growth year-on-year. On the contrary, share of local India rivals deeply dropped to $13.5 \%$ in the Q1 2017 from 40.5\% in Q1 2016 (See Table 3).

In 2015, Xiaomi started making smart phones in Brazil for local sale, promising to challenge rivals on price in the first step outside Asia for the world's 4th largest smart phone market. Mr. Hugo Barra, Xiaomi's global vice-president, said that Brazil was stage one of Latin America launch for Xiaomi, Mexico and Colombia will be next steps in the Latin America region. Xiaomi's launch in Brazil had been highly expected by consumers who keened to the company's homepage to secure a smart phone. However, the fundamental e-commerce infrastructure could not cope with the demand and customers began to lose their attention just less than 12 months after it launched its operations in the Brazilian market. Nearly a year after Xiaomi expanded to first market outside of Asia: Brazil, it will continue selling smart phone sales in Brazil but stop manufacturing these phones. It's a most important slow down for Xiaomi in the world's fourth-largest smart phone market. The Brazilan manufacturing of Xiaomi and its partner: Foxconn is going to an end before 2017. Xiaomi's vice president of international operations, Hugo Barra, said that the decision is due to constant changes in the regulations for manufacturing and e-commerce tax. 
Table 3. Top 5 Smartphone Companies in India (Q12017 - Q22016)

\begin{tabular}{lccccccc}
\hline Company & $\begin{array}{c}\text { Q12017 Market } \\
\text { Share }(\%)\end{array}$ & Company & $\begin{array}{c}\text { Q42016 Market } \\
\text { Share }(\%)\end{array}$ & Company & $\begin{array}{c}\text { Q32016 } \\
\text { Market Share } \\
(\%)\end{array}$ & $\begin{array}{c}\text { Company } \\
\begin{array}{c}\text { Q22016 } \\
\text { Market Share } \\
(\%)\end{array}\end{array}$ \\
\hline Samsung & 28.1 & Samsung & 25.1 & Samsung & 23.0 & Samsung & 25.1 \\
Xiaomi & $\mathbf{1 4 . 2}$ & Lenovo & 10.7 & Lenovo & 9.8 & Intex & 7.1 \\
Lenovo & 9.5 & Micromax & 9.9 & Micromax & 7.5 & Lenovo & 7.7 \\
OPPO & 9.3 & Reliance Jio & 8.6 & Reliance Jio & 7.0 & Micromax & 12.9 \\
Vivo & 10.5 & Xiaomi & $\mathbf{7 . 6}$ & Xiaomi & $\mathbf{7 . 4}$ & Reliance Jio & 6.8 \\
Others & 28.4 & Others & 38.1 & Others & 45.3 & Others & 40.4 \\
Total & 100 & Total & 100 & Total & 100 & Total & 100 \\
\hline
\end{tabular}

Source: IDC Qarterly Mobile Phone Tracker

\section{What can Xiaomi do to keep its growth and Competitiveness?}

\section{Methodology}

Data in this paper were collected form open sources such as Apple (2016), Gartner (2016), Huawei (2016), IDC (2016), OPPO (2016), TrendForce (2016), Vivo (2016), and Xiaomi (2016). We utilized David's Strategy-Formulation Analytical Framework with nine matrixes: EFE, IFE, CPM, SWOT, SPACE, BCG, IE, GSM, and QSPM (David, 2009, 2015). Delphi Method was employed in order to assess the weights and ratings in the nine matrixes. There were 120 EMBA students participated and discussed this case at a strategic seminar of one business school in China. The Delphi Method was developed in 1950 by Rand Corporation by a project supported by USAF in order to seek expert opinions about the strategy selection. The Delphi Method has been broadly utilized to strategic planning (Shiue and Lin, 2013; Murry and Hammons, 1995).

\section{Questions}

a. Please formulate matrixes for Xiaomi as following:

(1) The External Factor Evaluation (EFE) Matrix

(2) The Internal Factor Evaluation (IFE) Matrix

(3) The Competitive Profile Matrix (CPM)

(4) The Threats-Opportunities-Weakness-Strengths (TOWS) Matrix

(5) The Strategic Position and Action Evaluation (SPACE) Matrix

(6) The BCG Matrix

(7) The Internal-External (IE) Matrix

(8) The Grand Strategy Matrix (GSM)

(9) The Quantitative Strategic Planning Matrix (QSPM)

b. What kind of strategy should Xiaomi implement?

\section{Strategic planning for Xiaomi}

(1) The External Factor Evaluation (EFE) Matrix

An EFE Matrix permits strategists to review and calculate outside impact factors in terms of political, governmental, legal, cultural, demographic, economic, social, environmental, technological, and competitive information. Table 4 shows the External Factor Evaluation Matrix for Xiaomi. Overall, Xiaomi receives a 2.8 total weighted score, which indicating it is doing quite well with taking advantage of the external opportunities and avoiding the threats from industry and rivals. 
Table 4. EFE Matrix for Xiaomi

\begin{tabular}{|c|c|c|c|}
\hline Key External Factors & Weight & Rating & Weighted Score \\
\hline \multicolumn{4}{|l|}{ Opportunities $(\mathrm{O})$} \\
\hline 1. China's GDP had been growing $6.5-9 \%$ annually between $2011-2016$ & 0.15 & 3 & 0.45 \\
\hline $\begin{array}{l}\text { 2. Average salary had been growing from RMB } 3096 \text { in } 2010 \text { to RMB } 5169 \text { in } \\
2016\end{array}$ & 0.05 & 4 & 0.2 \\
\hline $\begin{array}{l}\text { 3. Sales of smart phones in China had growth from } 423.6 \text { millions (2014) to } \\
467.3 \text { millions (2016). }\end{array}$ & 0.15 & 3 & 0.45 \\
\hline $\begin{array}{l}\text { 4. Penetrations rates of smart phones in China were } 65 \% \text { and Japan is } 43 \% \text { in } \\
2016 \text {. }\end{array}$ & 0.15 & 3 & 0.45 \\
\hline 5. Coverage rates of 4G signal in China is over 50\% in July 2016. & 0.1 & 4 & 0.4 \\
\hline \multicolumn{4}{|l|}{$\begin{array}{ll} & \text { Threats }(\mathrm{T}) \\
\end{array}$} \\
\hline 1. Growth of China's economy is slowing down. & 0.1 & 3 & 0.3 \\
\hline $\begin{array}{l}\text { 2. Average price of smart phones in China was RMB } 1400 \text { (2014) but went up } \\
\text { to } 1800 \text { (2016). }\end{array}$ & 0.1 & 2 & 0.2 \\
\hline 3. Employment rates of collage graduates was $91 \%$ in 2015 & 0.05 & 2 & 0.1 \\
\hline 4. Stress Index of collage graduates went up from 16.93 (2012) to 18.39 (2016) & 0.05 & 2 & 0.1 \\
\hline $\begin{array}{l}\text { 5. Average salary of collage graduates went from } 2719 \text { (2011) up to RMB } \\
4765 \text { (2016). }\end{array}$ & 0.05 & 3 & 0.15 \\
\hline Total & 1.00 & & 2.8 \\
\hline
\end{tabular}

(2) The Internal Factor Evaluation (IFE) Matrix

An IFE Matrix sums up and appraises the main strengths and weaknesses in the functional areas of a firm such as marketing, finance, operation, $R \& D$ and so on. Moreover, The IFE Matrix also offers a foundation for identifying and evaluating relationships among those areas. Intuitive judgments are required in assembling an IFE Matrix. Overall, Xiaomi receives a 2.9 total weighted score, which indicating it is quite competitive in terms of its operations, marketing, finance, and so on (See Table 5).

Table 5. IFE Matrix for Xiaomi

\begin{tabular}{|c|c|c|c|}
\hline Key External Factors & Weight & Rating & Weighted Score \\
\hline \multicolumn{4}{|l|}{$\begin{array}{l} \\
\text { Strengths (S) }\end{array}$} \\
\hline $\begin{array}{l}\text { 1. Price is really competitive; the flagship prices from Mi } 1 \text { in } 2011 \text { to Mi } 6 \text { in } \\
2016 \text { are between RMB } 1999 \text { and } 2299 \text {. }\end{array}$ & 0.2 & 4 & 0.8 \\
\hline $\begin{array}{l}\text { 2. Sales of Mi } 5 \text { s and Mi } 5 \text { s Plus at the JD e-store reached } 100 \text { millions in } 15 \\
\text { minutes. }\end{array}$ & 0.1 & 4 & 0.4 \\
\hline 3. On-line sales reduce distribution and inventory costs & 0.1 & 3 & 0.3 \\
\hline $\begin{array}{l}\text { 4. Xiaomi is one of the leading smart phone company to have its smart home } \\
\text { system }\end{array}$ & 0.15 & 4 & 0.6 \\
\hline $\begin{array}{l}\text { 5. Xiaomi was No. } 8 \text { Smart phone vendor in the world and No. } 5 \text { in China } \\
\text { market in } 2016\end{array}$ & 0.1 & 3 & 0.3 \\
\hline \multicolumn{4}{|l|}{ Weaknesses (W) } \\
\hline 1. The sales growth of smart phones is weakening in 2016 & 0.1 & 1 & 0.1 \\
\hline $\begin{array}{l}\text { 2. Xiaomi is going to open } 1000 \text { stores within } 5 \text { years and give up only on-line } \\
\text { sales strategy }\end{array}$ & 0.05 & 2 & 0.1 \\
\hline 3. The profits margins of Xiaomi is predicted only around $3 \%$ & 0.05 & 2 & 0.1 \\
\hline $\begin{array}{l}\text { 4. The quality and quantity of patents for Xiaomi is not good enough to be a } \\
\text { leading smart phone company }\end{array}$ & 0.1 & 1 & 0.1 \\
\hline $\begin{array}{l}\text { 5. Factories can not provide enough quantities of smart phone so Mi fans have } \\
\text { to wait for a long time to seize new model of Mi phones on-line. }\end{array}$ & 0.05 & 2 & 0.1 \\
\hline Total & 1 & & 2.9 \\
\hline
\end{tabular}

Table 6. Competitive Profile Matrix (CPM) for Xiaomi and Its Competitors

\begin{tabular}{lccccccc}
\hline \multicolumn{1}{c}{ Critical Success Factors } & \multicolumn{2}{c}{ Xiaomi } & \multicolumn{2}{c}{ Huawei } & \multicolumn{2}{c}{ OPPO } \\
& Weight & Rating & $\begin{array}{c}\text { Weighted } \\
\text { Score }\end{array}$ & Rating & $\begin{array}{c}\text { Weighted } \\
\text { Score }\end{array}$ & Rating & $\begin{array}{c}\text { Weighted } \\
\text { Score }\end{array}$ \\
\hline 1. Product Quality & 0.1 & 3 & 0.3 & 4 & 0.4 & 3 & 0.3 \\
2. Market Share & 0.1 & 2 & 0.2 & 4 & 0.4 & 3 & 0.3 \\
3. Pricing & 0.15 & 4 & 0.6 & 2 & 0.3 & 3 & 0.45 \\
4. Innovation & 0.1 & 3 & 0.3 & 4 & 0.4 & 2 & 0.2 \\
5. Sales distribution & 0.05 & 2 & 0.1 & 3 & 0.15 & 4 & 0.2 \\
6. Revenues and profits & 0.15 & 2 & 0.3 & 4 & 0.6 & 3 & 0.45 \\
7. Customer loyalty & 0.05 & 3 & 0.15 & 4 & 0.2 & 3 & 0.15 \\
8. Global expansion & 0.05 & 3 & 0.15 & 4 & 0.2 & 3 & 0.15 \\
9. E-commerce & 0.15 & 4 & 0.6 & 3 & 0.45 & 2 & 0.3 \\
10. Leadership & 0.1 & 4 & 0.4 & 3 & 0.3 & 2 & 0.2 \\
\hline \multicolumn{1}{c}{ Total } & 1 & \multicolumn{7}{c}{3.1} & & 3.4 & & 2.7 \\
\hline
\end{tabular}




\section{(3) The Competitive Profile Matrix (CPM)}

The Competitive Profile Matrix (CPM) may identify a company's key rivals. Identifying Critical success factors is the most important process in constructing the CPM. The most important factors in the Table 6 are "pricing", "Revenues and profits" and "E-commerce" as indicated by weights of 0.15. Xiaomi is doing well in "pricing" and "E-commerce" but scores quite low in "Revenues and profits". Overall, Xiaomi is quite strong, as indicated by the total weighted score of 3.1, just after Huawei (3.4).

\section{(4) The Strengths-Weakness-Opportunities-Threats (SWOT) Matrix}

The Strengths-Weakness-Opportunities-Threats (SWOT) Matrix is an imperative matching implement that assists managers construct four types of strategies: SO (strengths-opportunities), WO (weaknesses-opportunities), ST (strengths-threats), and WT (weakness-threats) strategies. First, SO strategies exercise as firm's inside strengths to make the most of external opportunities. Second, WO strategies intend at improving internal weakness by making use of external opportunities. Third, ST strategies exercise a firm's strengths to keep away from or decrease the impact of outer threats. Finally, WT strategies are self-protective tactics directed at reducing inner weakness and avoiding outer threats. Tables 7-1 and 7-2 show the Strengths-Weakness-Opportunities-Threats (SWOT) Matrix for Xiaomi.

Table 7.1. SWOT Matrix for Xiaomi

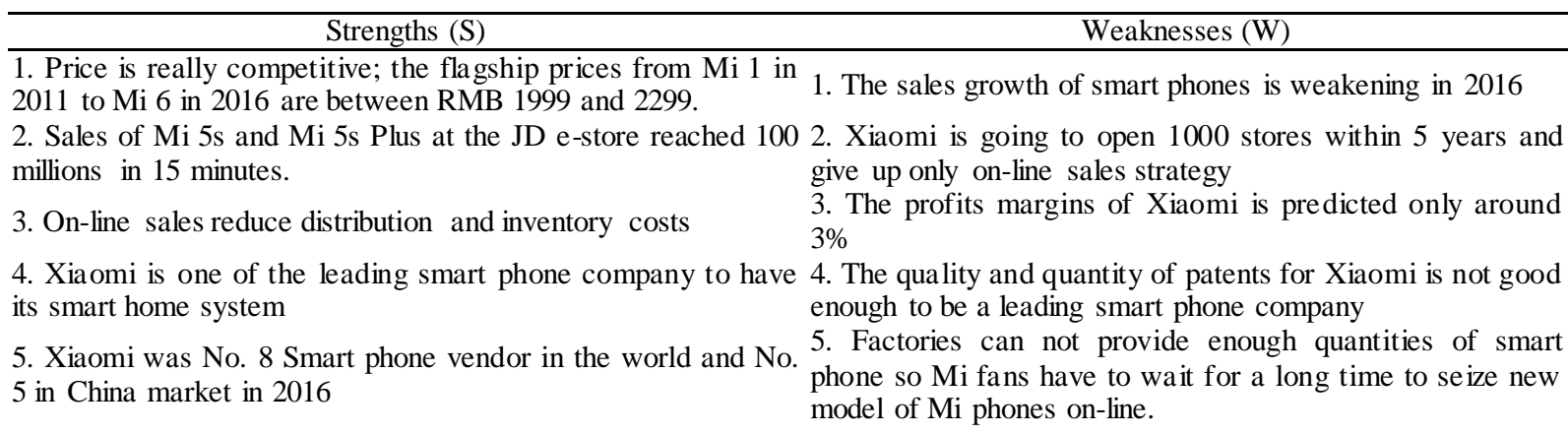

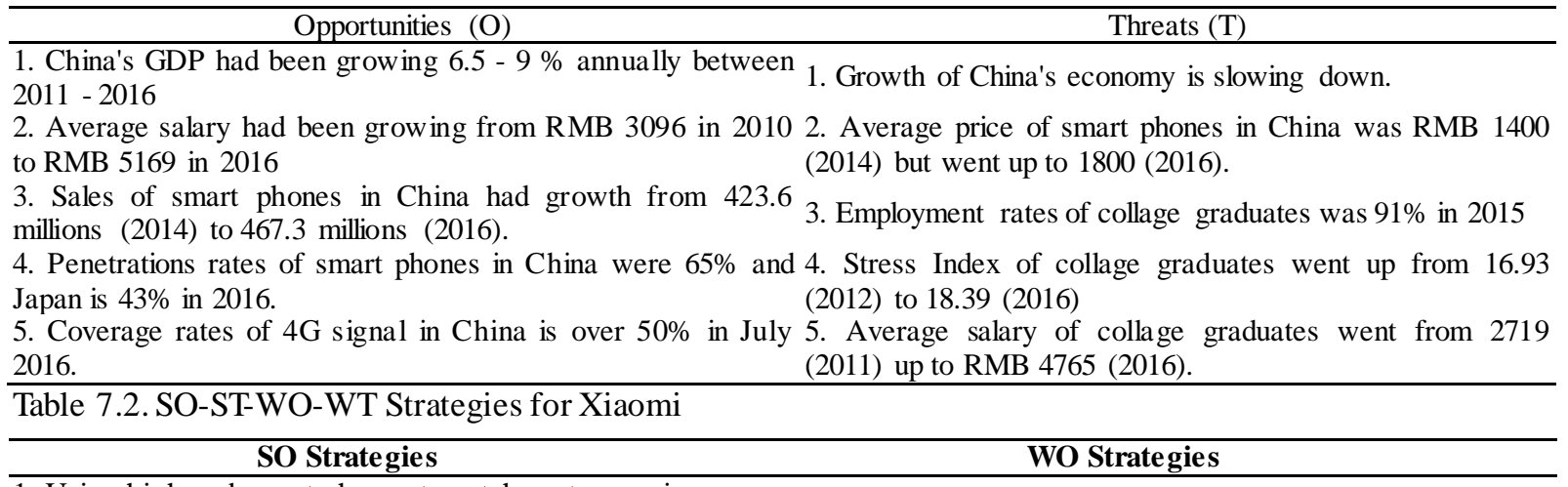
1. Using high-end smart phones to catch customers in 1 . Put money in R\&D in order to build up quantity and quality
USA and European Union. patents.

2. Going to emerging market by selling Red Mi smart 2. Building good relationships with suppliers in order to have enough phone in order to increase market shares worldwide. products on time.

\section{ST Strategies}

1. Keep providing low price models of Red Mi phones for young customers in China.

\section{WT Strategies}

1. Rivals such as OPPO and VIVO have more 200 thousands stores in China, Xiaomi may open thousands stores to sell smart phones soon.

2. Offering higher price models Mi flagship phones, in 2. Using low- price models under 100 USD for budget customers in which price can up to 2999 for high-end user in China. Africa.

3. Cooperating with car firms to enlarge its smart

home system into Internet of things.

\section{(5) The Strategic Position and Action Evaluation (SPACE) Matrix}

The Strategic Position and Action Evaluation (SPACE) Matrix with four-quadrant framework point out whether aggressive, conservative, defensive, or competitive strategies are most suitable for given company. The axes of the SPACE Matrix stand for two internal dimensions (FS: financial strength, and CA: competitive advantage) 
and two external dimensions (ES: environment stability, and IS: industry strength). These four factors are perhaps the most imperative determinants of a firm's strategic position on the whole. Xiaomi is in the aggressive quadrant, which can use backward, forward, horizontal integration; market penetration, market development, product development; and related diversification, unrelated diversification. (See Figure 1 and Table 8).

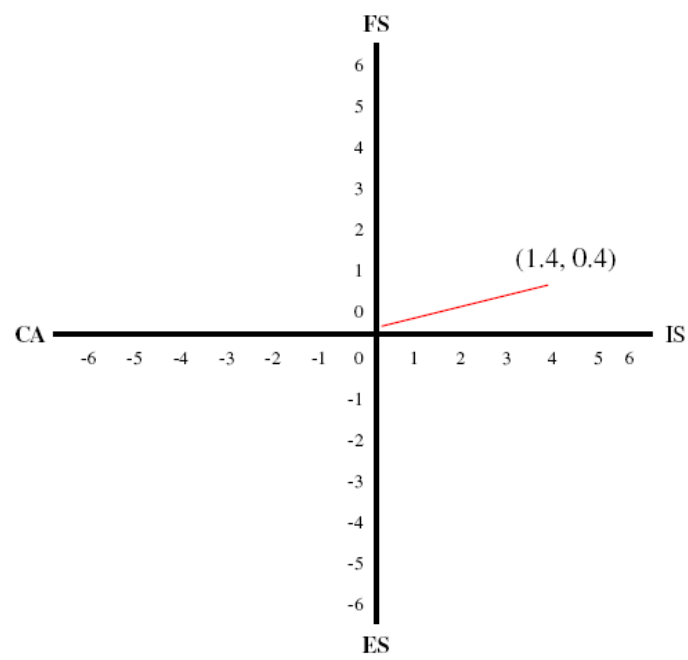

Figure 1. SPACE Matrix for Xiaomi

Table 8. Factors for the SPACE Matrix Axes of Xiaomi

\begin{tabular}{|c|c|c|c|}
\hline Internal Strategic Position & & External Strategic Position & \\
\hline Financial Strength (FS) & Rating & Environmental Stability $(\mathrm{ES})$ & Rating \\
\hline $\begin{array}{l}\text { 1. Xiaomi was valued as } 45 \text { billions US } \\
\text { dollars by venture capital in the end of } 2014\end{array}$ & 6 & $\begin{array}{l}\text { 1. China's GDP had been growing } 7-9 \% \\
\text { (2011-2015), but growth of China's economy } \\
\text { is slowing down. }\end{array}$ & -2 \\
\hline $\begin{array}{l}\text { 2. Xiaomi was estamiated only } 1.3 \% \\
\text { profitability rates and RMB } 300 \text { millions in } \\
2014 \text {. }\end{array}$ & 2 & $\begin{array}{l}\text { 2. Average salary had been growing from } \\
\text { RMB } 3096 \text { in } 2010 \text { to RMB } 5169 \text { in } 2015\end{array}$ & -5 \\
\hline $\begin{array}{l}\text { 3. Xiaomi's revenues reached RMB } 78 \\
\text { billions, only } 5 \% \text { increased year-on year. }\end{array}$ & 3 & $\begin{array}{l}\text { 3. employment rates of collage graduates } \\
\text { was } 91 \% \text { in } 2015\end{array}$ & -4 \\
\hline $\begin{array}{l}\text { 4. Huawei was the most profitable firm with } \\
8.6 \% \text { net profit margin, following by OPPO } \\
(8.2 \%) \text {, VIVO (7.9\%), but Xiaomi is } \\
\text { believed lower than these rivals in } 2015 \text {. }\end{array}$ & 2 & $\begin{array}{l}\text { 4. Stress Index of collage graduates went up } \\
\text { from } 16.93 \text { in } 2012 \text { to } 18.39 \text { in } 2015\end{array}$ & -4 \\
\hline $\begin{array}{l}\text { 5. Sales of Mi } 5 \text { s and Mi } 5 \text { s Plus reached } 100 \\
\text { million within } 15 \text { minutes at JD e-store in } \\
\text { first release day. }\end{array}$ & 6 & $\begin{array}{l}\text { 5. Average salary of collage garduates went } \\
\text { from } 2719 \text { in } 2011 \text { upto RMB } 4765 \text { in } 2015 .\end{array}$ & -2 \\
\hline & 3.8 & & -3.4 \\
\hline Competitive Advantage (CA) & & $\begin{array}{c}\text { Industry Strength (IS) } \\
\end{array}$ & \\
\hline $\begin{array}{l}\text { 1. On-line sales reduce distribution and } \\
\text { inventory costs }\end{array}$ & -1 & $\begin{array}{l}\text { 1. Sales of smart phones in China had } \\
\text { growth from } 423.6 \text { millions in } 2014 \text { to } 437.8 \\
\text { millions in } 2015 .\end{array}$ & 3 \\
\hline $\begin{array}{l}\text { 2. Xiaomi is one of the leading smart phone } \\
\text { company to have its smart home system }\end{array}$ & -1 & $\begin{array}{l}\text { 2. Penetrations rates of smart phones in } \\
\text { China is } 58 \% \text { and Japan is } 39 \% \text { in } 2015 .\end{array}$ & 4 \\
\hline $\begin{array}{l}\text { 3. Price is really competitive; the flagship } \\
\text { prices from Mi } 1 \text { in } 2011 \text { to Mi } 5 \text { s in } 2016 \\
\text { always are RMB } 1999 \text {. }\end{array}$ & -2 & $\begin{array}{l}\text { 3. Coverage rates of } 4 \mathrm{G} \text { signal in China is } \\
\text { over } 50 \% \text { in July } 2016 .\end{array}$ & 5 \\
\hline $\begin{array}{l}\text { 4. Xiaomi is going to open } 1000 \text { stores } \\
\text { within } 5 \text { years and give up only on-line sales } \\
\text { strategy }\end{array}$ & -4 & $\begin{array}{l}\text { 4. Average price of smart phones in China } \\
\text { was RMB } 1400 \text { in } 2014 \text { but went up to } 1800 \\
\text { in } 2015 \text {. }\end{array}$ & 3 \\
\hline $\begin{array}{l}\text { 5. Xiaomi was No. } 4 \text { Smart phone vendor in } \\
\text { the world and No. } 1 \text { in China market }\end{array}$ & -2 & $\begin{array}{l}\text { 5. The sales of growth smart phones are } \\
\text { predicted as } 6 \% \text { in } 2016 \text {, down form } 10.1 \% \\
\text { in } 2015 \text { worldwide }\end{array}$ & 2 \\
\hline & -2 & & 3.4 \\
\hline $\begin{array}{l}\text { Conclusion } \\
\text { x-axis: }(-2)+(3.4)=1.4 \\
\quad \text { Recommended Strategies: }\end{array}$ & $\begin{array}{l}\text { Backwa } \\
\text { Market } 1 \\
\text { Related }\end{array}$ & $\begin{array}{l}\text { y-axis: }(3.8)+(-3.4)=0.4 \\
\text { oorizontal integration } \\
\text { Market development, Product development } \\
n \text {, Unrelated diversification }\end{array}$ & \\
\hline
\end{tabular}




\section{(6) BCG Matrix}

The main benefits of the BCG Matrix are that it draws attentions to the cash flow, investment qualities, and needs of a firm's a mixture of divisions. First, question marks, when a di vision falls into the quadrant I may have a low relative market share position and fights in a high-growth industry. Second, stars, quadrant II firm signify the firm's best long-run opportunities for growth and prosperity. Third, cash cows, a division positioned in quadrant III may have a high comparative market share position with competing in a low-growth industry. Finally, quadrant IV divisions of the firms may have a low comparative market share position with competing in a slow- or no-market-growth industry. In the end, firms should try hard to accomplish a portfolio of divisions that are Stars and cash cows. Due to the complex to obtain related quantitative data, we use Delphi Method to locate each division into suitable quadrant (See Figure 2).

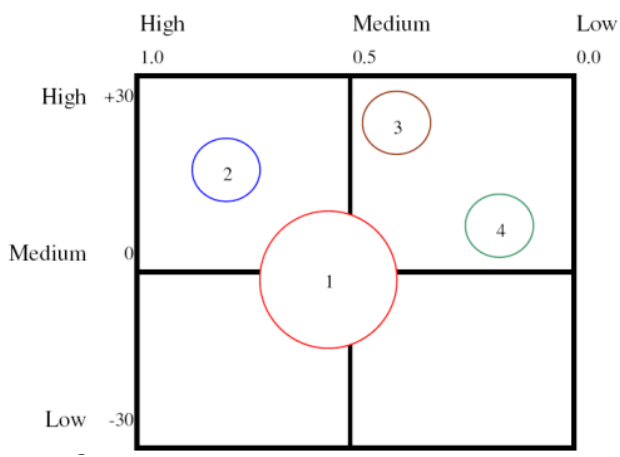

Note:

1: Smart phone division

2: Smart home ecosystem division

3: Internet service division

4: MIUI OS division

(7) The Internal-External (IE) Matrix

The Internal-External (IE) Matrix positions a firm's a range of divisions in a nine-cell exhibit. In Figure 3, the IE Matrix engages plotting divisions in a diagram. The IE Matrix requires more information about the divisions than the BCG Matrix. The IE Matrix is based on two major dimensions: the IFE total weighted scores (x-axis) and the EFE total weighted scores (y-axis). The IE Matrix can be divided into three main regions that have dissimilar insinuations. First, the advice for divisions that fall into cells I, II, or IV can be explained as grow and build: intensive or integrative strategies are recommended. Second, di visions that fall into cells III, V, or VII can be explained as hold and maintain: market penetration and product development are recommended. Third, common advices for divisions that fall into cells VI, VIII, or IX are harvest or divest: retrenchment and divestiture are recommended. Since it is difficult to obtain related quantitative data, we use Delphi Method to locate each division into proper quadrant (See Figure 3).

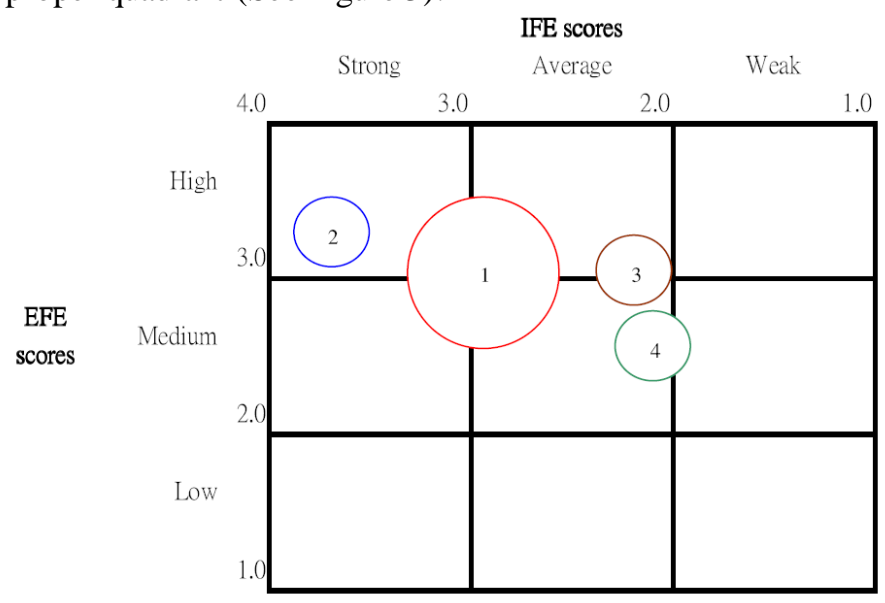

Figure 3. The IE Matrix for Xiaomi 
Note:

1: Smart phone division

2: Smart home ecosystem division

3: Internet service division

4: MIUI OS division

(8) The Grand Strategy Matrix (GSM)

The Grand Strategy Matrix (GSM) has turn into a admired instrument for preparing alternative strategies. All firms can be positioned in one of the GSM's four quadrants. This Matrix is based on two evaluative dimensions: competitive position (x-axis) and market growth (y-axis). Any market (industry) whose annual growth in sales exceeds 5 percent can be viewed to have rapid growth. Firms located in Quadrant I of the GSM are in an outstanding position. Suitable strategies for these firms are concentration on current markets or products, integrations and related diversification. Firms positioned in Quadrant II need to appraise their current approach to the marketplace critically.

Since these firms are in a rapid-market growth industry, intensive strategies may be good choices for these firms. However, if these firms are short of competitive advantages, then horizontal integration is often a attractive selection.

Quadrant III organizations compete in slow-growth industries with weak competitive positions. These firms must make some radical change quickly to keep away from further decline or the possibility of liquidation. Wide-ranging cost and asset reduction (retrenchment) should be chased at the first place. A substitute strategy is to move resources away from the present business into dissimilar areas (diversify). The final choices for Quadrant III businesses are divestiture or liquidation when they run out of stream. Finally, businesses in Quadrant IV have a strong competitive position with setting in slow-growth industry. These firms have the power to commence diversified projects into more promising growth industry (market) by using related or unrelated diversification strategies (See Figure 4).

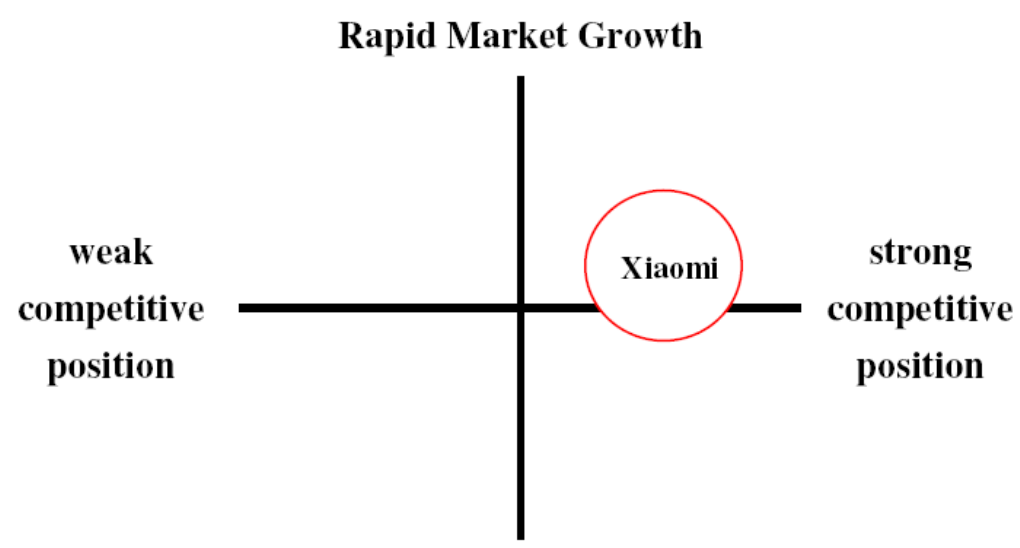

Slow Market Growth

Figure 4. Grand Strategy Matrix for Xiaomi

(9) The Quantitative Strategic Planning Matrix (QSPM)

The Quantitative Strategic Planning Matrix (QSPM) indicates which alternative strategies are best. The QSPM uses input from Stage 1 analyses and matching results form Stage 2 analyses to decide objectively among alternative strategies. The QSPM is a tool that allows strategists to evaluate alternative strategies objectively, requires good intuitive judgment, based on previously identified external and internal critical success factors. The left column of a QSPM consists of information obtained directly form the EFE Matrix and IFE Matrix (See Table 9). 
Table 9. Quantitative Strategic Planning Matrix for Xiaomi

\begin{tabular}{|c|c|c|c|c|c|c|c|}
\hline \multirow[b]{2}{*}{ Key Factors } & \multirow[b]{2}{*}{ Weight } & \multicolumn{2}{|c|}{$\begin{array}{c}\text { Market } \\
\text { development }\end{array}$} & \multicolumn{2}{|c|}{$\begin{array}{c}\text { Product } \\
\text { development }\end{array}$} & \multicolumn{2}{|c|}{$\begin{array}{c}\text { Related } \\
\text { diversification }\end{array}$} \\
\hline & & $\mathrm{AS}$ & TAS & $\mathrm{AS}$ & TAS & AS & TAS \\
\hline \multicolumn{8}{|l|}{ Opportunities $(O)$} \\
\hline $\begin{array}{l}\text { 1. China's GDP had been growing } 6.5-9 \% \text { annually between } \\
2011-2016\end{array}$ & 0.15 & 4 & 0.6 & 2 & 0.3 & 3 & 0.45 \\
\hline $\begin{array}{l}\text { 2. Average salary had been growing from RMB } 3096 \text { in } 2010 \text { to } \\
\text { RMB } 5169 \text { in } 2016\end{array}$ & 0.05 & 3 & 0.15 & 4 & 0.2 & 2 & 0.1 \\
\hline $\begin{array}{l}\text { 3. Sales of smart phones in China had growth from } 423.6 \\
\text { millions (2014) to } 467.3 \text { millions (2016). }\end{array}$ & 0.15 & 4 & 0.6 & 1 & 0.15 & 2 & 0.3 \\
\hline $\begin{array}{l}\text { 4. Penetrations rates of smart phones in China were } 65 \% \text { and } \\
\text { Japan is } 43 \% \text { in } 2016 \text {. }\end{array}$ & 0.15 & 4 & 0.6 & 2 & 0.3 & 3 & 0.45 \\
\hline 5. Coverage rates of $4 \mathrm{G}$ signal in China is over $50 \%$ in July 2016. & 0.1 & 3 & 0.3 & 2 & 0.2 & 4 & 0.4 \\
\hline \multicolumn{8}{|l|}{ Threats $(T)$} \\
\hline 1. Growth of China's economy is slowing down. & 0.1 & 4 & 0.4 & 2 & 0.2 & 3 & 0.3 \\
\hline $\begin{array}{l}\text { 2. Average price of smart phones in China was RMB } 1400 \\
\text { (2014) but went up to } 1800(2016) \text {. }\end{array}$ & 0.1 & 3 & 0.3 & 4 & 0.4 & 2 & 0.2 \\
\hline 3. Employment rates of collage graduates was $91 \%$ in 2015 & 0.05 & 4 & 0.2 & 1 & 0.05 & 3 & 0.15 \\
\hline $\begin{array}{l}\text { 4. Stress Index of collage graduates went up from } 16.93 \text { (2012) to } \\
18.39 \text { (2016) }\end{array}$ & 0.05 & 3 & 0.15 & 1 & 0.05 & 4 & 0.2 \\
\hline $\begin{array}{l}\text { 5. Average salary of collage graduates went from } 2719 \text { (2011) up } \\
\text { to RMB } 4765 \text { (2016). }\end{array}$ & 0.05 & 3 & 0.15 & 4 & 0.2 & 2 & 0.1 \\
\hline & 1.00 & & & & & & \\
\hline \multicolumn{8}{|l|}{ Strengths $(S)$} \\
\hline $\begin{array}{l}\text { 1. Price is really competitive; the flagship prices from Mi } 1 \text { in } \\
2011 \text { to Mi } 6 \text { in } 2016 \text { are between RMB } 1999 \text { and } 2299 .\end{array}$ & 0.2 & 3 & 0.6 & 4 & 0.8 & 2 & 0.4 \\
\hline $\begin{array}{l}\text { 2. Sales of Mi } 5 \text { s and Mi } 5 \text { s Plus at the JD e-store reached } 100 \\
\text { millions in } 15 \text { minutes. }\end{array}$ & 0.1 & 3 & 0.3 & 4 & 0.4 & 2 & 0.2 \\
\hline 3. On-line sales reduce distribution and inventory costs & 0.1 & 4 & 0.4 & 3 & 0.3 & 2 & 0.2 \\
\hline $\begin{array}{l}\text { 4. Xiaomi is one of the leading smart phone company to have its } \\
\text { smart home system }\end{array}$ & 0.15 & 3 & 0.45 & 2 & 0.3 & 4 & 0.6 \\
\hline $\begin{array}{l}\text { 5. Xiaomi was No. } 8 \text { Smart phone vendor in the world and No. } 5 \\
\text { in China market in } 2016\end{array}$ & 0.1 & 4 & 0.4 & 2 & 0.2 & 3 & 0.3 \\
\hline \multicolumn{8}{|l|}{ Weaknesses $(W)$} \\
\hline 1. The sales growth of smart phones is weakening in 2016 & 0.1 & 3 & 0.3 & 2 & 0.2 & 4 & 0.4 \\
\hline $\begin{array}{l}\text { 2. Xiaomi is going to open } 1000 \text { stores within } 5 \text { years and give up } \\
\text { only on-line sales strategy }\end{array}$ & 0.05 & 3 & 0.15 & 4 & 0.2 & 2 & 0.1 \\
\hline 3. The profits margins of Xiaomi is predicted only around $3 \%$ & 0.05 & 3 & 0.15 & 2 & 0.1 & 4 & 0.2 \\
\hline $\begin{array}{l}\text { 4. The quality and quantity of patents for Xiaomi is not good } \\
\text { enough to be a leading smart phone company }\end{array}$ & 0.1 & 3 & 0.3 & 4 & 0.4 & 2 & 0.2 \\
\hline $\begin{array}{l}\text { 5. Factories can not provide enough quantities of smart phone so } \\
\text { Mi fans have to wait for a long time to seize new model of Mi } \\
\text { phones on-line. }\end{array}$ & $\begin{array}{l}0.05 \\
1.00 \\
\end{array}$ & 4 & 0.2 & 2 & 0.1 & 3 & 0.15 \\
\hline Total & 1.00 & & 6.7 & & 5.05 & & 5.4 \\
\hline
\end{tabular}

\section{Suggestions}

In Table 9, three alternative strategy types: (1) market development, (2) product development, and (3) related diversification are being considered by Xiaomi. Note by sum total attractiveness scores of (1) market development: 6.7 , (2) product development: 5.05, (3) related diversification: 5.4 that the analysis indicates the firm should first implement market development, and then carry out related diversification in terms of cooperatelevel strategies.

Once we make sure the order of strategy types, we may go back to SWOT Matrix to find what kind of SO-ST-WO-WT strategies can be performed. There are two SO strategies can be utilized: (1) using high-end smart phones to catch customers in USA and European Union, and (2) going to emerging market by selling Red Mi smart phone in order to increase market shares worldwide; one WT strategy can be exercised: Using lowprice models under 100 USD for budget customers in Africa. These strategies are classified as market development. Second, one ST strategy: cooperating with car firms to enlarge its smart home system into Internet of things is categorized into related diversification, which may be considered to put into effect after three market development strategies.

According to the results from BCG Matrix and IE Matrix, the division level strategies are as following: the first Smart phone division may use (1) Product Development and Market Development. Second, Smart home 
ecosystem division may use (1) Product Development, (2) Market Development, (3) Market Penetration, and (4) Integration. Third, Internet service division may use (1) Product Development, (2) Market Development, and (3) Market Penetration. Finally, MIUI OS division may use (1) Product Development, and (2) Market Penetration.

\section{Acknowledgment}

This research was presented at the 2017 AIB Meeting in Dubai. We are thankful to the three anonymous reviewers for their insightful comments and suggestions.

\section{References}

Ansoff, I. (1987). Strategic Management of Technology. Journal of Business Strategy, 7(3), 28-39. https://doi.org/10.1108/eb039162

Biggadike, R. (1981). The Contribution of Marketing to Strategic Management. Academy of Management Review, 6(4), 621-632.

Camphell, A., \& Yeung, S. (1991). Creating a Sense of Mission. Long Range Planning, 24(4), 10-20. https://doi.org/10.1016/0024-6301(91)90002-6

Chen, M. J. (1996). Competitor Analysis and Interfirm Rivalry: Toward a Theoretical Integration, Academy of Management Review, 21(1), 100-134.

David, F. (1986). The Strategic Planning Matrix - A Quantitative Approach. Long Range Planning, 19(5), 102-107. https://doi.org/10.1016/0024-6301(86)90015-4

David, F. (1988). How Companies Define Their Mission. Long Range Planning, 22(3), 90-97.

David, F. (2009). Strategic Management: Concepts, 12e, NJ: Parson.

David, F. (2015). Strategic Management: A Competitive Advantage Approach, Concepts \& Cases, 15e, NY: Pearson.

Drucker, P. (1974). Management: Tasks, Responsibilities, and Practices, NY: Harper \& Row.

Freund, Y. (1988). Critical Success Factors. Planning Review, 16(4), 20-23. https://doi.org/10.1108/eb054225

Harris, J., Shaw, R. J., \& Sommers, W. (1983). The Strategic Management of Technology. Planning Review, 11(11), 28-35. https://doi.org/10.1108/eb054013

King, W. (1983). Integrating strength-weakness analysis into strategic planning. Journal of Business Research, 2(4), 475-487. https://doi.org/10.1016/0148-2963(83)90006-1

Murry, J. W., Jr. \& Hammons, J. O. (1995). Delphi: A Versatile Methodology for Conducting Qualitative Research. Review of Higher Education, 18(4), 423-436. https://doi.org/10.1353/rhe.1995.0008

Okoli, C., \& Pawlowski, S. (2004). The Delphi method as a research tool: an example, design considerations and applications. Information \& Management, 42(1), 15-29. https://doi.org/10.1016/j.im.2003.11.002

Parnell, J. (2003). Five Critical Challenges in Strategy Making. SAM Advanced Management Journal, 68(2), $15-22$.

Schein, E. H. (1996). Three Cultures of Management: The Key to Organizational Learning. Sloan Management Review, 38(1), 9-20.

Shiue, Y., Liu, H., \& Lin, C. (2013). Strategy alignment of value system based on core value by integrating the delphi method, dialectic method and important-performance analysis. Journal of Accounting, Finance \& Management Strategy, 8(1), 69-95.

Tilles, S. (1963). How to Evaluate Corporate Strategy. Harvard Business Review, 41(4), 111-121.

Weihrich, H. (1982). The TOWS Matrix: A Tool for Situational Analysis. Long Range Planning, 15(2), 54-66. https://doi.org/10.1016/0024-6301(82)90120-0

Apple (2016) http://www.apple.com/

Gartner (2016) http://www.gartner.com/

Huawei (2016) http://www.huawei.com

IDC (2016) http://www.idc.com/

OPPO (2016) http://www.oppo.com/

TrendForce (2016) http://www.trendforce.com/ 
Vivo (2016) http://www.vivoglobal.com/

Xiaomi (2016) http://xiaomi-mi.com

\section{Copyrights}

Copyright for this article is retained by the author(s), with first publication rights granted to the journal.

This is an open-access article distributed under the terms and conditions of the Creative Commons Attribution license (http://creativecommons.org/licenses/by/4.0/). 